\title{
Effectiveness of Kasugamycin Against Erwinia amylovora and its Potential Use for Managing Fire Blight of Pear
}

J. E. Adaskaveg, Department of Plant Pathology and Microbiology, University of California, Riverside 92521; H. Förster, Department of Plant Pathology, University of California, Davis 95616; and M. L. Wade, Arysta LifeScience, Roseville, CA 95678

\begin{abstract}
Adaskaveg, J. E., Förster, H., and Wade, M. L. 2011. Effectiveness of kasugamycin against Erwinia amylovora and its potential use for managing fire blight of pear. Plant Dis. 95:448-454.

Comparative field studies on the management of fire blight were conducted in California on Asian and Bartlett pear using single-bactericide, mixture, and rotation treatments of selected compounds. Treatment efficacy was evaluated based on the natural occurrence of the disease or after inoculation with Erwinia amylovora. Kasugamycin at $100 \mathrm{mg} /$ liter demonstrated similar or higher pre- and post-infection activity than the industry standards, streptomycin and oxytetracycline. Phytotoxicity caused by kasugamycin was observed only when five or six sequential weekly applications were done. In a six-spray rotation program including three bactericides (copper, kasugamycin, and oxytetracycline), with each being used twice, phytotoxicity was minor. Baseline sensitivity concentrations for kasugamycin were established

for growth of 376 isolates of E. amylovora from California. Values for the lowest concentration where a reduction in growth on nutrient agar was observed ranged from 3.5 to $18.3 \mathrm{mg} / \mathrm{liter}$, with a mean value of 8.7 $\mathrm{mg} /$ liter. Values for $\geq 95 \%$ inhibition of growth ranged from 6.9 to 46.7 $\mathrm{mg} / \mathrm{liter}$, with a mean value of $18.5 \mathrm{mg} / \mathrm{liter}$. These inhibitory values for kasugamycin were higher than those for streptomycin or oxytetracycline. The in vitro activity of all three compounds was highly dependent on the agar medium used in the sensitivity assay. The activity of kasugamycin was also highly dependent on the $\mathrm{pH}$ of the medium and was significantly higher at $\mathrm{pH} 5.1$ than $\mathrm{pH}$ 7.3. With the planned registration in the United States, kasugamycin represents the first new, highly effective bactericide for managing fire blight in over 40 years.
\end{abstract}

Fire blight, caused by the bacterium Erwinia amylovora (Burrill), is one of the most important diseases of pome fruit trees and is especially destructive on pear (European pear, Pyrus communis L.; and Asian or apple pear, P. pyrifolia (Burm.) Nakai). The disease is indigenous to North America but has spread worldwide $(7,28,32)$. Overwintering cankers are considered the main survival sites and sources of primary inoculum the following spring $(8,28,32)$. Primary infections in the spring occur on flowers, and epidemics can develop when warm temperatures $\left(>18^{\circ} \mathrm{C}\right)$ prevail during bloom and inoculum is spread by insects and rain $(8,22,28,32)$. Secondary infections occur on later-developing flowers and on leaves and young fruitlets. In California, the bloom period of pear and apple is often prolonged, with flowering continuing after the main bloom (i.e., rat-tail bloom) because of insufficient chilling hours. Although less abundant, these secondary flowers are much more likely to become diseased because the warmer temperatures at this time of the year favor bacterial growth. Primary and secondary infections may develop into branch and trunk tissues and, if uncontrolled, the tree may eventually die (32).

The prolonged infection period in the spring and systemic spread of the pathogen within the tree contribute to the difficulty of managing fire blight. In addition to removing and destroying diseased plant material by pruning, appropriately timed bactericide applications that target primary and secondary infections as well as epiphytic growth of E. amylovora on flowers are among the most effective components of an integrated fire blight management strategy. Current chemical control programs for fire blight are based on protective schedules. Most available compounds are not systemic, with the exception of streptomycin, which may have curative action (21). Only a few efficacious treatments are currently available.

Corresponding author: J. E. Adaskaveg, E-mail: jim.adaskaveg@ucr.edu

Accepted for publication 29 November 2010.

doi:10.1094/PDIS-09-10-0679

(C) 2011 The American Phytopathological Society
Control with copper compounds is satisfactory only when disease incidence is low to moderate (32). In addition, because copper treatments commonly are phytotoxic to leaves and cause russeting of fruit that is undesirable for most pome fruit cultivars, their use is mainly restricted to dormant-period and early-bloom applications (21). The antibiotic streptomycin has been used to manage fire blight for over 50 years. Resistance to streptomycin in populations of E. amylovora, however, is widespread in California $(3,23)$ and in other growing areas of the United States and worldwide (13). This seriously compromises the efficacy of this treatment. Oxytetracycline is considered less effective than streptomycin (21) and, recently, reduced sensitivity of E. amylovora against this antibiotic was reported for the first time in some locations in California (1). Biocontrol using various bacterial antagonists can also reduce the incidence of fire blight although, in many cases, these treatments were less effective than streptomycin or oxytetracycline (11). Additionally, certain fungicides had low to moderate efficacy against fire blight in some studies (31) but not others (16).

One strategy to manage fire blight is to continue to develop effective alternative chemical treatments that could be integrated into resistance management programs to decrease the risk of resistance to each chemical treatment. The antibiotic kasugamycin, first described in the 1960s, is an aminoglycoside produced by Streptomyces kasugaensis (31). Kasugamycin interferes with bacterial protein synthesis by inhibiting the binding of aminoacyl-tRNA to the messenger-ribosome complex, leading to an inhibition of polypeptide synthesis (27). Thus, it has a mode of action different from streptomycin or oxytetracycline $(21,27)$. The antibiotic is inhibitory toward species of Erwinia, Pseudomonas, and Xanthomonas, as well as several fungal plant pathogens (21) and has been widely used for management of rice blast caused by Pyricularia oryzae (35). Kasugamycin was tested against fire blight of pome fruit previously and showed a wide range of efficacy ranging from no significant control to highly effective $(4,21)$. However, due to phytotoxic effects described as "burning" of flowers and leaves of apple and pear at the rates used (6), registration on these crops was never pursued. In contrast to streptomycin and oxytetracycline, kasugamycin is not being used in human and animal medicine and has very low toxicity against mammals and fish $(19,35)$. 
The effectiveness of an agricultural pesticide against a target pest or disease may be influenced by many factors, including the physical and chemical properties of the compound and the environmental conditions that occur during and after a pesticide application (25). One of the most important factors that can affect the biological activity or stability (e.g., half-life) of a chemical is the $\mathrm{pH}$ of the water used for its application. Many pesticides used in fruit production are stable over a wide range of $\mathrm{pH}$ conditions; however, a number of them are unstable in alkaline environments (25). For example, the half-lives of the fungicides captan, iprodione, and maneb are greatly reduced at high $\mathrm{pH}$ as opposed to low $\mathrm{pH}$ (29). The half-life of kasugamycin is also reduced under alkaline conditions, although much less than that of the fungicides listed above (29). Information on the biological activity of kasugamycin to E. amylovora at different $\mathrm{pH}$ values is not known. Thus, $\mathrm{pH}$ effects on bacterial inhibition in a growth medium should be established when assessing the initial overall or baseline sensitivity for populations of the pathogen to kasugamycin.

Therefore, the objectives of this study were to reevaluate the use of kasugamycin for managing fire blight and identify use strategies that have no negative effects on the pome fruit host, assess the effect of $\mathrm{pH}$ and growth medium on the activity of kasugamycin against $E$. amylovora, and determine the baseline sensitivity of $E$. amylovora to kasugamycin.

\section{Materials and Methods}

Pre- and post-infection activity of kasugamycin in controlling fire blight. In field tests on Asian pear ('Shinko' and '20th Century') at the University of California, Davis, treatments were applied to run-off to branches with open flowers using a household hand sprayer on 15 and 22 March 2010 on the two cultivars, respectively. To evaluate preinfection activity, treatments were applied and allowed to air dry for 1 or $2 \mathrm{~h}$, and then flowers were inoculated with E. amylovora. To evaluate post-infection activity, flowers were inoculated and treated after $16 \mathrm{~h}$. Treatments included a water control and aqueous preparations of streptomycin (AgriMycin 17; Nufarm Americas, Inc., Burr Ridge, IL) at 100 mg/liter, oxytetracycline (Mycoshield; Nufarm Americas, Inc.) at 200 $\mathrm{mg} / \mathrm{liter}$, kasugamycin (Kasumin 2L; Arysta LifeScience, Cary, $\mathrm{NC})$ at $100 \mathrm{mg} / \mathrm{liter}$, and a mixture of kasugamycin at $100 \mathrm{mg} / \mathrm{liter}$ and mancozeb (Dithane M45; Dow AgroSciences, Indianapolis, IN) at $5,400 \mathrm{mg} /$ liter. Inoculations were done with a strain of $E$. amylovora $\left(10^{6} \mathrm{CFU} / \mathrm{ml}\right.$ in sterile distilled water), isolated from diseased flowers in a commercial Bartlett pear orchard in Marysville, CA, and determined to be sensitive to all compounds evaluated. Inoculations were applied to run-off using a hand sprayer in late afternoon and inoculated branches were enclosed in white plastic bags for 16 to $18 \mathrm{~h}$ to maintain leaf wetness and reflect sunlight to prevent overheating inside the bags. Disease was evaluated after 10 to 14 days as incidence (the number of diseased flowers per 20 to 50 flowers used for each replication expressed as a percentage). All treatments were applied to each of four single-tree replications and the experiment was conducted twice, once on each of the two pear cultivars.

Field tests on the efficacy of fire blight treatments in commercial orchards. Five field trials with three to six approximately weekly applications per spring season were done in commercial 'Bartlett' pear orchards in Sutter (2006, 2007, 2009, and 2010) and Yuba (2006) Counties, CA, where fire blight occurred in previous years and where no resistance to streptomycin was known to be present in populations of E. amylovora (2). Application dates were: 6 and 13 April (60 to $80 \%$ bloom), 20 and 26 April (full bloom), 3 and 10 May (petal fall) in 2006 (the last application was done only at the Yuba County orchard); 19 March (60 to 80\% bloom), 26 March (full bloom), and 3 April (petal fall) in 2007; 23 March (60 to $80 \%$ bloom), 31 March (full bloom), and 7 April (petal fall) in 2009; and 24 March (60 to 80\% bloom), 29 March (full bloom), and 6 April (petal fall) in 2010. A randomized complete block design with four to six single-tree replications was used for each treatment. All treatments were applied at a rate of 830 liters/ha using a gasoline-powered, backpack air-blast sprayer (Model SR420; Stihl Inc., Virginia Beach, VA). Single-active-ingredient treatments that were evaluated in selected trials were streptomycin (Agri-Mycin 17) at $100 \mathrm{mg} /$ liter, oxytetracycline (Mycoshield) at $200 \mathrm{mg} /$ liter, kasugamycin (Kasumin 2L) at $100 \mathrm{mg} / \mathrm{liter}$, mancozeb (Dithane F45 or M45) at 5,400 mg/liter, and copper hydroxide (Kocide 3000; Du Pont de Nemours and Co., Wilmington, DE) at $280 \mathrm{mg} / \mathrm{liter}$. In mixture treatments, kasugamycin $(100 \mathrm{mg} / \mathrm{liter})$ was applied with mancozeb $(5,400 \mathrm{mg} / \mathrm{liter})$, streptomycin (100 $\mathrm{mg} / \mathrm{liter}$ ), oxytetracycline (200 mg/liter), or dodine (Syllit FL, 510 mg/liter; Aceto Agricultural Chemical Corp., Lake Success, NY). The rotation treatment was copper hydroxide $(320 \mathrm{mg} / \mathrm{liter})$ followed by kasugamycin (100 mg/liter), and then followed by oxytetracycline $(200 \mathrm{mg} / \mathrm{liter})$.

In the three experiments conducted during the 2006 and 2007 seasons, treatment effects on the natural occurrence of fire blight were compared. For this, disease was evaluated in mid-April (10 to 14 days after the last application). In 2009 and 2010, trees were inoculated with E. amylovora $\left(10^{5} \mathrm{CFU} / \mathrm{ml}\right) 3 \mathrm{~h}$ after the last bactericide application. Disease was then evaluated after 10 days. For all evaluations, disease was expressed as incidence based on the number of diseased spurs per 50 to 100 spurs evaluated for each replication. Trees of selected treatments were also assessed for potential phytotoxic effects. Phytotoxicity incidence was based on the number of fruiting spurs with leaves showing marginal injury per 20 spurs evaluated for each replication; severity was visually evaluated and was based on a rating scale of 0 to 5 , where $0=$ no symptoms and $1=<10,2=11$ to $25,3=26$ to $50,4=51$ to 75 , and $5=76$ to $100 \%$ of leaf margin necrotic.

Isolation of $\boldsymbol{E}$. amylovora and bacterial culturing. In total, 376 isolates of E. amylovora were obtained from pear orchards in the major growing areas in central and northern California between 2006 and 2009. Infected plant material (flowers, fruit, stems, and pedicels) was surface disinfested for 1 min using sodium hypochlorite at $400 \mathrm{mg} / \mathrm{liter}$, rinsed with sterile water, cut into sections (approximately 1 by 2 by $5 \mathrm{~mm}$ ), and incubated in $1 \mathrm{ml}$ of sterile water for 15 to $30 \mathrm{~min}$ to allow bacteria to stream out of the tissue, and the aqueous suspension was streaked onto yeast extract-dextrose- $\mathrm{CaCO}_{3}$ agar (34). Single colonies were transferred and the identity of the isolates as E. amylovora was verified by colony morphology and by polymerase chain reaction using primers specific for the ubiquitous E. amylovora plasmid pEA29 (5). The presence of a 1-kb DNA fragment after gel electrophoresis confirmed a positive identification.

Laboratory studies on inhibition of $E$. amylovora by kasugamycin, streptomycin, oxytetracycline, and mancozeb. The spiral gradient dilution method $(9,20)$ was used to evaluate the in vitro sensitivity of all isolates of $E$. amylovora collected to kasugamycin and of eight isolates to mancozeb. For this, a radial concentration gradient of kasugamycin (Kasumin 2L) or mancozeb (Dithane M45) was established in nutrient agar (NA) media (Difco Laboratories, Detroit) in 15-cm-diameter petri dishes by spirally plating out an aqueous stock concentration of kasugamycin at $10,000 \mathrm{mg} /$ liter or mancozeb at 5,000 mg/liter using a spiral plater (Autoplate 4000; Spiral Biotech, Inc., Norwood, MA). After radially streaking out suspensions of the test bacteria $\left(10 \mu \mathrm{l}\right.$ of $10^{8}$ $\mathrm{CFU} / \mathrm{ml}$, as determined by measurement of optical density at 600 $\mathrm{nm}$ ) along the concentration gradient, plates were incubated for 2 days at $25^{\circ} \mathrm{C}$. Measurements were taken for two inhibitory concentrations as determined visually: (i) the lowest inhibitory concentration (LIC; the lowest concentration where inhibition of bacterial growth was observed; i.e., where the bacterial streak became less dense visually), and (ii) the minimum inhibitory concentration (MIC; the minimal concentration that inhibited growth by $\geq 95 \%$ ). The actual antibiotic concentrations were obtained by entering the radial distances of inhibition (measured from the center of the plate) into the Spiral Gradient Endpoint computer program (Spiral Biotech, Inc.). Each isolate was evaluated in two independent experiments with two or four replications per experiment. 
Eight randomly selected isolates were evaluated for their sensitivity against kasugamycin, streptomycin, and oxytetracycline using the same method as described above and using NA, King's medium B (KMB; 15), Luria-Bertani agar, Czapek agar (Difco Laboratories), Kado medium 523 (14), and a modified yeast-salts agar (YSA; $0.5 \mathrm{~g}$ of $\mathrm{NH}_{4} \mathrm{H}_{2} \mathrm{PO}_{4}, 0.5 \mathrm{~g}$ of $\mathrm{K}_{2} \mathrm{HPO}_{4}, 0.2 \mathrm{~g}$ of $\mathrm{MgSO}_{4} \cdot 7 \mathrm{H}_{2} \mathrm{O}, 5.0 \mathrm{~g}$ of $\mathrm{NaCl}, 5.0 \mathrm{~g}$ of yeast extract, and $15.0 \mathrm{~g}$ of agar per liter). Stock concentrations used in the spiral plating for streptomycin (streptomycin sulfate; Sigma-Aldrich, St. Louis), and oxytetracycline (oxytetracycline hydrochloride; Sigma-Aldrich) were 1,000 and $500 \mathrm{mg} / \mathrm{liter}$, respectively. Each isolate was evaluated in two experiments, with four replications per experiment.

In additional studies, the effect of $\mathrm{pH}$ of the culture medium on the activity of kasugamycin was investigated. To obtain selected $\mathrm{pH}$ values, a previously published method (17) was adopted. For this, $1.1 \mathrm{ml}$ of a sterilized buffer $(1.3 \mathrm{~g}$ of citric acid, $1.9 \mathrm{~g}$ of glycine, and $1.9 \mathrm{~g}$ of $\mathrm{KH}_{2} \mathrm{PO}_{4}$ per $50 \mathrm{ml}$ of water) was added to 18.9 $\mathrm{ml}$ of nutrient broth (Difco Laboratories) and the $\mathrm{pH}$ was adjusted to mean values of 5.1 (5.0 to 5.2) or $7.3(7.1$ to 7.5$)$ using $1 \mathrm{~N}$ $\mathrm{NaOH}$. Measurements of $\mathrm{pH}$ were done with a $\mathrm{pH}$ meter (Orion 5 Star; Thermo Electron Corp., Beverly, MA). The test was conducted in microtiter plates (no. 269787; Nunc, Roskilde, Denmark) $(0.2 \mathrm{ml}$ of reaction volume per well) with an initial bacterial concentration of $10^{7} \mathrm{CFU} / \mathrm{ml}$. Plates were incubated on a shaker at 180 $\mathrm{rpm}$ at $25^{\circ} \mathrm{C}$. After $12 \mathrm{~h}$, bacterial growth was measured at $600 \mathrm{~nm}$ using a plate reader (Wallac Victor ${ }^{2} 1420$ Multilabel Counter; PerkinElmer Life Sciences, Boston, MA). The assay was done three times with one isolate of E. amylovora (isolate E2) and using four replications per experiment.

Statistical analysis of data. For repeated experiments, homogeneity of variance was tested using Bartlett's test of homogeneity. When variance was homogeneous, data were combined and further statistically analyzed. Incidence values for disease and phytotoxicity were arcsine transformed, whereas severity values for phytotoxicity were not transformed. Data were then analyzed using analysis of variance (ANOVA) and least significant difference (LSD) mean separation procedures (SAS version 9.1; SAS Institute Inc., Cary, NC). Mean inhibitory values of E. amylovora for kasugamycin

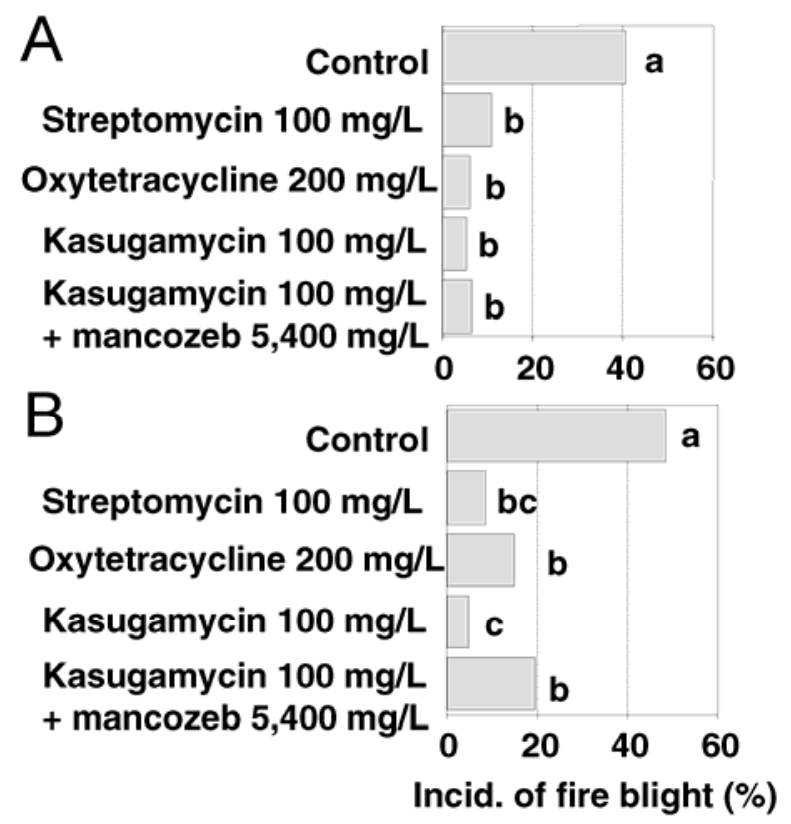

Fig. 1. Evaluation of bactericides for control of fire blight of '20th Century' and 'Shinko' Asian pear in field trials. A, Preinfection and B, post-infection activity. Treatments were applied to run-off using a hand sprayer either 1 or $2 \mathrm{~h}$ before (i.e., preinfection activity) or $16 \mathrm{~h}$ after (i.e., post-infection activity) inoculation with Erwinia amylovora $\left(1 \times 10^{6}\right.$ $\mathrm{CFU} / \mathrm{ml})$. Disease was evaluated as the incidence of blighted flowers per 20 to 50 flowers for each of the four replications after 10 to 14 days. Data were combined for the two cultivars after testing for homogeneity of variance. were plotted in frequency histograms. For this, values for inhibitory concentrations were first $\log _{10}$-transformed and the bin (i.e., LIC category or MIC category) width $h$ for the transformed data was determined using the method of Scott (24) with the equation $h_{n}=3.49 \mathrm{sn}^{-1 / 3}$, where $s$ is an estimate of the standard deviation and $n$ is the number of isolates evaluated. Standard deviations were calculated from mean $\log _{10}$-transformed inhibitory values. The number of bins was then determined over the range of inhibitory values. For comparisons of the inhibitory effects of antibiotics using different agar media, mean values for inhibitory concentrations of eight isolates were compared using ANOVA and LSD separation procedures.

For comparing the inhibitory activity of kasugamycin at different $\mathrm{pH}$ values of the growth medium, values for net growth were first determined by subtracting initial optical density readings from the final readings. For each $\mathrm{pH}$ range and concentration of kasugamycin, relative growth was based on growth in nonamended medium. Data were analyzed as a factorial experiment using ANOVA and LSD mean separation procedures.

To determine whether multiple resistance between kasugamycin and streptomycin or oxytetracycline was present, mean LIC values for kasugamycin were plotted against those for the other two bactericides (that were determined previously) in pairwise comparisons. In these comparisons, 376 and 257 strains were evaluated for streptomycin and oxytetracycline, respectively. Values for kasugamycin were regressed against those for streptomycin or oxytetracycline using ANOVA and regression procedures (SAS version 9.1).

\section{Results}

Pre- and post-infection activity of kasugamycin in controlling fire blight. For the two experiments conducted on Asian pear 'Shinko' and '20th Century', variances were homogeneous for each of the two treatment-inoculation timings; however, significant differences were found between timings. Thus, data were combined for the two cultivars for each application timing. When flowers were first treated and then inoculated after 1 to $2 \mathrm{~h}$, all treatments, including kasugamycin and kasugamycin-mancozeb, as well as the registered streptomycin and oxytetracycline, reduced the incidence of fire blight compared with the control (Fig. 1A). The incidence of diseased flowers was significantly $(P<0.001)$ reduced from $40.8 \%$ in the untreated control to between $5.4 \%$ (kasugamycin) and 11\% (streptomycin). When flowers were first inoculated and then treated after $16 \mathrm{~h}$, all treatments significantly reduced the incidence compared with the control (Fig. 1B). Kasugamycin was significantly $(P<0.001)$ more effective than oxytetracycline or kasugamycin-mancozeb. Streptomycin showed an intermediate efficacy.

Field tests on the efficacy of fire blight treatments in commercial orchards. In three field trials on 'Bartlett' pear conducted in 2 years at two locations, the natural incidence of fire blight ranged from $15.9 \%$ (average of two tests in 2006) to $27.3 \%$ (2007). All treatments significantly $(P<0.0001)$ reduced blossom blight and most demonstrated a similar efficacy, except for oxytetracycline in 2006 (Table 1). Among treatments, the incidence ranged between $1.5 \%$ (kasugamycin) and $4.5 \%$ (oxytetracycline) in 2006 and between $2.5 \%$ (streptomycin) and $7.3 \%$ (oxytetracycline) in 2007.

In two field trials where trees were inoculated with E. amylovora after the last bactericide application, all treatments evaluated also significantly $(P<0.0001)$ reduced the incidence of fire blight, and no significant differences were observed among treatments (Table 2). The incidence of disease in the nontreated control was $52.3 \%$ in 2009 and $54.8 \%$ in 2010. The incidence among treatments ranged from $10.0 \%$ (kasugamycin-mancozeb) to $24.4 \%$ (oxytetracycline) in 2009 and from $9.0 \%$ (oxytetracycline) to $14.5 \%$ (copper hydroxide) in 2010.

Phytotoxicity on 'Bartlett' pear leaves was not observed after two consecutive weekly applications with kasugamycin but was present after five to six weekly applications at 100 to $150 \mathrm{mg} / \mathrm{liter}$ on leaves as a slight marginal burn and on harvested fruit as a 
single, circular ( 1 to $1.5 \mathrm{~cm}$ in diameter) mottled lesion per fruit. No phytotoxicity was present in the control or after treatments with oxytetracycline (Table 3). The incidence of phytotoxicity symptoms was highest at the $150-\mathrm{mg} /$ liter rate of kasugamycin applied (i.e., 64.9\%) and was significantly $(P<0.0001)$ lower at the 100 $\mathrm{mg} / \mathrm{liter}$ rate (i.e., $39.7 \%$ ). The severity of phytotoxicity was very low, as indicated by ratings between 0.1 and 0.7 on a rating scale from 0 to 5 (Table 3 ).

Laboratory studies on inhibition of $E$. amylovora by kasugamycin, streptomycin, oxytetracycline, and mancozeb. Values for the lowest concentration (LIC) of kasugamycin where a reduction in growth on NA was observed among 376 isolates of $E$. amylovora ranged from 3.5 to $18.3 \mathrm{mg} / \mathrm{liter}$, with a mean value of $8.7 \mathrm{mg} / \mathrm{liter}$ (Fig. 2A). Values for the antibiotic where $\geq 95 \%$ of growth was inhibited (MIC) ranged from 6.9 to $46.7 \mathrm{mg} / \mathrm{liter}$, with a mean value of $18.5 \mathrm{mg} / \mathrm{liter}$ (Fig. 2B). In all, $35 \%$ of the total number of isolates were resistant to streptomycin at 6 to $>50 \mathrm{mg} / \mathrm{liter}$ (J. E. Adaskaveg, unpublished data). The $P$ values for the regression models of LIC values of kasugamycin plotted against those for oxytetracycline or streptomycin were highly significant $(P<$ 0.0001). Still, correlation coefficients were low for both regressions $\left(r^{2}=0.07\right.$ or 0.05 , respectively; Fig. $3 \mathrm{~A}$ and B). Mancozeb was also inhibitory to E. amylovora with average (range) LIC and MIC values of $3.75 \mathrm{mg} / \mathrm{liter}$ (2.94 to $4.66 \mathrm{mg} / \mathrm{liter}$ ) and 5.27 $\mathrm{mg} /$ liter (4.11 to $6.59 \mathrm{mg} / \mathrm{liter}$ ), respectively.

When kasugamycin, streptomycin, and oxytetracycline were tested for their inhibitory effect against growth of eight randomly selected isolates of E. amylovora using six different growth media, variances were homogeneous among isolates. For the combined data set, significant $(P<0.0001)$ differences were observed among the media. Inhibition by each of the three compounds was lowest (LIC values were highest) using YSA but growth responses for the remaining media were different for kasugamycin, streptomycin, and oxytetracycline (Table 4). For kasugamycin and oxytetracycline, inhibition was greatest using NA whereas, for streptomycin, it was greatest using either NA, Czapek agar, or KMB. Among the media, there were 6.5-fold differences in inhibition for kasugamycin, 4.2-fold differences for streptomycin, and 20-fold differences for oxytetracycline.

The in vitro inhibition by kasugamycin was also highly dependent on the $\mathrm{pH}$ of the culture medium. Growth of E. amylovora using nutrient broth not amended with kasugamycin and adjusted to pH 5.1 was significantly $(P<0.0001)$ increased by 20.6 or $28.2 \%$ compared with growth using nonadjusted nutrient broth or broth

Table 1. Evaluation of bactericides for fire blight management in field trials on 'Bartlett' pear in 2006 (two locations) and 2007 (one location)

\begin{tabular}{lccr}
\hline & & \multicolumn{2}{c}{$\begin{array}{c}\text { Incidence of } \\
\text { fire blight }(\mathbf{\%})^{\mathbf{y}}\end{array}$} \\
\cline { 3 - 4 } Treatment $^{\mathbf{z}}$ & Rate (mg/liter) & $\mathbf{2 0 0 6}$ & $\mathbf{2 0 0 7}$ \\
\hline Control & $\ldots$ & $15.9 \mathrm{a}$ & $27.3 \mathrm{a}$ \\
Kasugamycin & 100 & $1.5 \mathrm{c}$ & $5.7 \mathrm{~b}$ \\
Streptomycin & 100 & $2.0 \mathrm{c}$ & $2.5 \mathrm{~b}$ \\
Oxytetracycline & 200 & $4.5 \mathrm{~b}$ & $7.3 \mathrm{~b}$ \\
Mancozeb & 5,400 & $\mathrm{ND}$ & $4.0 \mathrm{~b}$ \\
Kasugamycin + mancozeb & $100+5,400$ & $\mathrm{ND}$ & $4.0 \mathrm{~b}$ \\
Kasugamycin + streptomycin & $100+100$ & $\mathrm{ND}$ & $3.2 \mathrm{~b}$ \\
Copper hydroxide/ & & & \\
kasugamycin/oxytetracycline & $320 / 100 / 200$ & $4.3 \mathrm{~b}$ & $4.8 \mathrm{~b}$ \\
\hline
\end{tabular}

${ }^{\mathrm{y}}$ Disease was evaluated in mid-April of each year and was expressed as percent diseased spurs per 50 to 100 spurs evaluated for each of four to six single-tree replications. Mean values followed by the same letter are not significantly different based on analysis of variance and least significant difference mean separation procedures. $\mathrm{ND}=$ not done.

z Applications were done using a gasoline-powered, back-pack sprayer at 830 liters/ha. Application dates were: 60 to $80 \%$ bloom (6 and 13 April 2006 and 19 March 2007), full bloom (20 and 26 April 2006 and 26 March 2007), and petal fall (3 and 10 May 2006 and 3 April 2007). The application on 10 May in 2006 was done only at one location. Treatments 6 and 7 were mixtures, whereas treatment 8 was a rotation program. adjusted to $\mathrm{pH} 7.3$, respectively. Relative inhibition of growth in the presence of kasugamycin was significantly $(P<0.0001)$ higher at $\mathrm{pH} 5.1$ than at $\mathrm{pH} 7.3$ (Table 5). Thus, compared with the nonamended control, relative growth in the presence of kasugamycin at $5 \mathrm{mg} / \mathrm{liter}$ was $78.9 \%$ at $\mathrm{pH} 7.3$ and $13.8 \%$ at $\mathrm{pH} 5.1$. In the presence of kasugamycin at $10 \mathrm{mg} /$ liter, growth was $64.9 \%$ at $\mathrm{pH} 7.3$ and $3.9 \%$ at $\mathrm{pH} 5.1$.

\section{Discussion}

This research adds valuable information toward a sustainable strategy for using the antibiotic kasugamycin for managing fire blight and potentially other bacterial diseases of plants $(1,3)$ in the United States. We demonstrated that kasugamycin is an effective alternative treatment for managing fire blight of pear and apple (1), as was also indicated recently by others $(12,26,36)$. In orchards where no resistance to streptomycin was known to be present in the pathogen populations, kasugamycin had a similar or higher efficacy compared with streptomycin and oxytetracycline. Our in vitro studies demonstrated no cross-resistance between kasugamycin

Table 2. Evaluation of bactericides for fire blight management in field trials on 'Bartlett' pear in 2009 and 2010

\begin{tabular}{|c|c|c|c|c|c|}
\hline \multirow[b]{2}{*}{ Treatment $^{\mathrm{z}}$} & & \multirow{2}{*}{\multicolumn{2}{|c|}{ Rate (mg/liter) }} & \multicolumn{2}{|c|}{$\begin{array}{l}\text { Incidence of } \\
\text { fire blight }(\%)^{y}\end{array}$} \\
\hline & & & & 2009 & 2010 \\
\hline \multicolumn{4}{|l|}{ Control } & $52.3 \mathrm{a}$ & $54.8 \mathrm{a}$ \\
\hline \multicolumn{2}{|l|}{ Kasugamycin } & 10 & & $11.2 \mathrm{~b}$ & $12.4 \mathrm{~b}$ \\
\hline \multicolumn{2}{|l|}{ Streptomycin } & 10 & & $19.2 \mathrm{~b}$ & $14.3 \mathrm{~b}$ \\
\hline \multicolumn{2}{|l|}{ Oxytetracycline } & 20 & & $24.4 \mathrm{~b}$ & $9.0 \mathrm{~b}$ \\
\hline \multicolumn{2}{|l|}{ Mancozeb } & 5,40 & & $18.4 \mathrm{~b}$ & $11.9 \mathrm{~b}$ \\
\hline \multicolumn{2}{|l|}{ Copper hydroxide } & 28 & & $18.8 \mathrm{~b}$ & $14.5 \mathrm{~b}$ \\
\hline \multicolumn{2}{|c|}{ Kasugamycin + mancozeb } & & $+5,400$ & $10.0 \mathrm{~b}$ & $14.0 \mathrm{~b}$ \\
\hline \multicolumn{2}{|c|}{ Kasugamycin + streptomycin } & & +100 & $18.8 \mathrm{~b}$ & $11.0 \mathrm{~b}$ \\
\hline \multicolumn{6}{|c|}{$\begin{array}{l}\text { y Trees were inoculated with Erwinia amylovora }\left(10^{5} \mathrm{CFU} / \mathrm{m}\right. \\
\text { approximately } 3 \mathrm{~h} \text { after the last bactericide application and disease wa } \\
\text { evaluated in mid-April. For all evaluations, disease was expressed a } \\
\text { percent diseased spurs per } 50 \text { to } 100 \text { spurs evaluated for each of four t } \\
\text { six single-tree replications. Mean values followed by the same letter ar } \\
\text { not significantly different based on analysis of variance and leas } \\
\text { significant difference mean separation procedures. } \\
\text { z Applications were done using a gasoline-powered, back-pack sprayer a } \\
830 \text { liters/ha. Applications were done at } 60 \text { to } 80 \% \text { bloom (23 Marc } \\
2009 \text { and } 24 \text { March 2010), full bloom ( } 31 \text { March } 2009 \text { and } 29 \text { Marc } \\
2010 \text { ), and petal fall (7 April } 2009 \text { and } 6 \text { April 2010). }\end{array}$} \\
\hline \multicolumn{6}{|c|}{$\begin{array}{l}\text { Table 3. Phytotoxicity ratings on 'Bartlett' pear leaves in field trials aft } \\
\text { treatment with selected bactericides }\end{array}$} \\
\hline \multirow[b]{2}{*}{ Treatment $^{y}$} & \multirow{2}{*}{\multicolumn{2}{|c|}{ Rate (mg/liter) }} & \multicolumn{3}{|c|}{ Phytotoxicity $^{\mathrm{x}}$} \\
\hline & & & Inciden & $(\%)$ & everity \\
\hline & \multicolumn{2}{|c|}{$0 \mathrm{~d}$} & $0 \mathrm{~d}$ \\
\hline \multicolumn{3}{|l|}{$\begin{array}{l}\text { Control } \\
\text { Oxytetracyclin }\end{array}$} & \multicolumn{2}{|c|}{$0 \mathrm{~d}$} & $0 \mathrm{~d}$ \\
\hline Kasugamycin & 100 & & \multicolumn{2}{|c|}{$39.7 \mathrm{~b}$} & $0.4 \mathrm{~b}$ \\
\hline Kasugamycin & 125 & & \multicolumn{2}{|c|}{$38.0 \mathrm{~b}$} & $0.4 \mathrm{~b}$ \\
\hline Kasugamycin & 150 & & & $0.7 \mathrm{a}$ \\
\hline Rotation $^{\mathrm{z}}$ & $320 / 100$ & & \multicolumn{2}{|c|}{$13.3 \mathrm{c}$} & $0.1 \mathrm{c}$ \\
\hline
\end{tabular}

${ }^{\mathrm{x}}$ Phytotoxicity ratings were obtained in mid-May and are the mean of two experiments (one done at each of two locations) in 2006. Incidence is based on the number of fruiting spurs with leaves showing marginal injury per 20 spurs evaluated for each of four to six single-tree replications. Severity rating is based on a rating scale of 0 to 5 , where $0=$ no symptoms and $1=<10,2=11$ to $25,3=26$ to $50,4=51$ to 75 , and 5 $=76$ to $100 \%$ of leaf margin necrotic. For each column, values followed by the same letter are not significantly different according to an analysis of variance and least significant mean separation procedures $(P<0.05)$.

${ }^{y}$ Six sprays at approximately 1 -week intervals were applied between early April and mid-May using a gasoline-powered, back-pack sprayer adjusted to 830 liters/ha.

${ }^{\mathrm{z}}$ For the rotation (copper hydroxide/kasugamycin/oxytetracycline), each compound was applied once and the sequence was repeated for a total of six weekly sprays. 
and streptomycin or oxytetracycline; consequently, kasugamycin may be valuable for managing fire blight where resistance to streptomycin has made control of the disease difficult. Furthermore, because insensitivity to oxytetracycline has been recently reported at some locations in California (1), an alternative bactericide with a mode of action different from registered compounds could help to prevent the further selection and spread of oxytetracycline insensitivity.

Previous studies on the use of ethylene-bis-dithiocarbamate fungicides for the control of fire blight indicated inconsistent efficacy ranging from unsatisfactory to acceptable $(16,32,37,38)$. Efficacy at selected rates of the compounds evaluated was generally acceptable when disease incidence was light to moderate. Under moderate disease pressure in our studies, mancozeb applied at the maximum registered rate (e.g., $5400 \mathrm{mg} /$ liter) significantly reduced the incidence of fire blight and was as effective as kasugamycin or streptomycin. Mancozeb was also inhibitory in our in vitro assays, as previously reported for maneb (37). Although mixture treatments of kasugamycin with mancozeb resulted in no additive effect, a combination treatment could be a strategy to prevent resistance from developing due to the distinct modes of action of the two compounds $(30,35)$. Selected formulations of mancozeb are registered in the United States on pome fruit for managing some fungal diseases as well as fire blight. For the control of fire blight, some labels of mancozeb recommend its use in combination with copper compounds.

The preinfection (protective) activity of kasugamycin was similar to streptomycin and oxytetracycline, whereas the 16-h post- infection (curative) activity was similar to streptomycin but significantly higher than for oxytetracycline. All three compounds are known to enter the plant tissue $(19,33)$. A comparative study on the systemic properties of these antibiotics, however, has not been done. Uptake of oxytetracycline may be lower than that of streptomycin or kasugamycin, possibly explaining the reduced post-infection activity of oxytetracycline. Alternatively, streptomycin has been shown to be bactericidal, whereas oxytetracycline is bacteriostatic (18), and the development of established infections could be more difficult to prevent with a bacteriostatic compound. The postinfection activity of a kasugamycin-mancozeb mixture was reduced in our small-scale field tests compared with using kasugamycin alone. Thus, mixture treatments of kasugamycin with mancozeb will be most beneficial when used as protective applications.

Phytotoxicity caused by kasugamycin has been the main reason for not pursuing previously a registration of the antibiotic for fire blight management on pome fruit crops in the United States and elsewhere (6). We observed phytotoxicity in our trials but only when five to six sequential applications were done. The incidence and severity of phytotoxicity were higher at a rate of $150 \mathrm{mg} / \mathrm{liter}$ compared with $100 \mathrm{mg} / \mathrm{liter}$ but efficacy was not improved using the higher rate (1). Thus, the $100-\mathrm{mg} /$ liter rate is suggested as the labeled rate for managing fire blight. Additionally, in a six-spray rotation program with three bactericides (i.e., copper, kasugamycin, and oxytetracycline), with each compound being used twice, phytotoxicity was minor. Furthermore, in our field trials, minor circular lesions on some harvested fruit did not lead to an increased
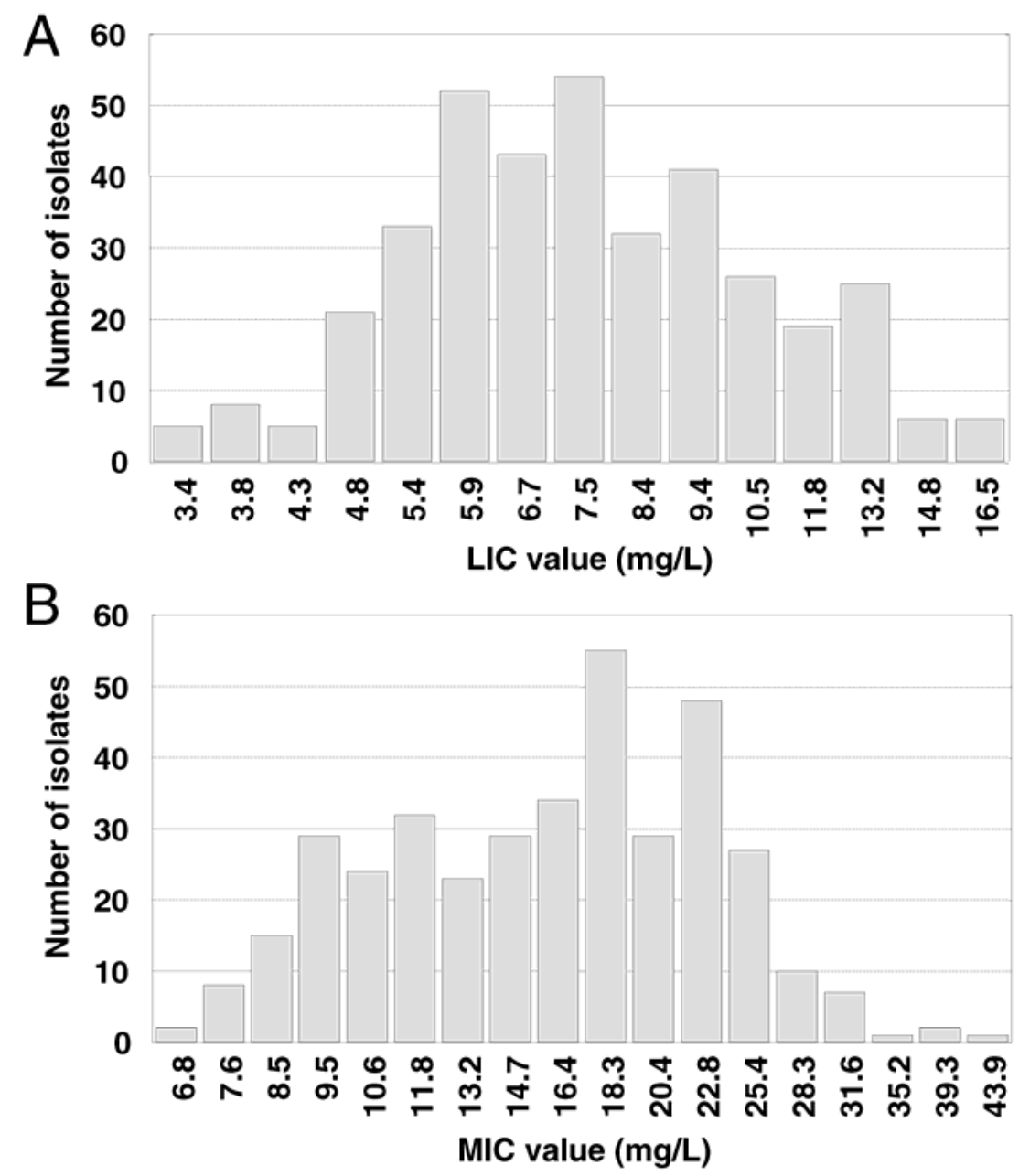

Fig. 2. In vitro sensitivity to kasugamycin of 376 isolates of Erwinia amylovora collected throughout California pear-growing regions. A, Lowest inhibitory concentration (LIC; the lowest concentration where inhibition of bacterial growth was observed; i.e., where the bacterial streak became less dense visually), and B, minimal inhibitory concentration (MIC; concentration that inhibits growth by $\geq 95 \%$ ) were determined using the spiral gradient dilution method. Bar height indicates the number of isolates within each bin and bin width was based on Scott's method using $\log _{10}$-transformed values (24). 
incidence of off-grades at the packinghouse (before the crop was destroyed in accordance with nonregistered use). The circular lesions were probably the result of injury, where spray droplets accumulated on the lower surface of the fruit when late-season (fruit more than half grown) applications were done. Label restrictions that limit application to no more than two sequential applications and a total number of four applications per season should mitigate phytotoxicity effects (and potentially reduce the selection of resistant strains). Thus, strategies for use of kasugamycin on 'Bartlett' pear have been identified that maximize efficacy and minimize the occurrence of phytotoxicity under our experimental conditions.

The inhibition of bacterial growth by a chemical compound is typically described as the MIC or the lowest concentration of an antimicrobial that prevents growth of the organism. We could not easily obtain these concentrations for kasugamycin, streptomycin, and oxytetracycline because there was generally a very gradual reduction in growth with increasing concentrations of the antimicrobials. This made it difficult to assess where growth was completely prevented. Thus, we chose to quantify in vitro inhibitory activity as both LIC and MIC values (defined here as the minimum concentration to inhibit growth by $95 \%$ ). Using these two values, shifts in sensitivities among strains in sample populations can be detected.

Although in field trials, the efficacy of kasugamycin against fire blight was similar to streptomycin and oxytetracycline (equal amounts of active ingredient for kasugamycin and streptomycin and double the amount of active ingredient for oxytetracycline), concentrations required to inhibit bacterial growth in vitro were higher for kasugamycin than for the other two antibiotics. In a comparison of different agar media used in the sensitivity assay, the in vitro activity of all three compounds was found to be highly dependent on the medium used and there were differences for the three compounds. Kasugamycin and oxytetracycline had the lowest LIC values on NA, whereas LIC values for streptomycin were similar for four of the six media used in this study.

The activity of kasugamycin was also highly dependent on the $\mathrm{pH}$ of the medium. This was not tested for streptomycin and oxy-

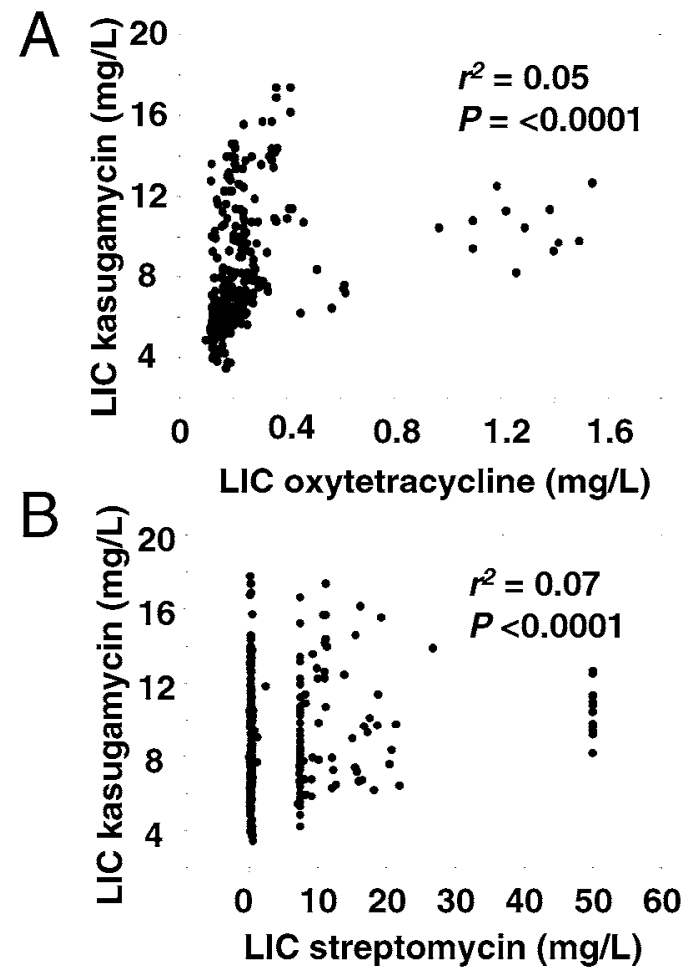

Fig. 3. Scatter plots of lowest inhibitory concentrations (LICs) of kasugamycin for growth of Erwinia amylovora plotted against those for A, streptomycin (376 isolates evaluated) and B, oxytetracycline (257 isolates evaluated). Coefficients of determination $\left(r^{2}\right)$ and $P$ values for the linear regressions are indicated. tetracycline. Similar to previous studies with $P$. oryzae (10), we found that the activity of kasugamycin against $E$. amylovora was significantly higher at $\mathrm{pH} 5.1$ compared with $\mathrm{pH}$ 7.3. In contrast, Hamada et al. (10) found that inhibition of Pseudomonas spp. by kasugamycin was greater at $\mathrm{pH} 7$ than at $\mathrm{pH} 5$ or 6 . This difference in $\mathrm{pH}$ response among different organisms cannot be easily explained. The effect of $\mathrm{pH}$ on the inhibition by kasugamycin may be important in preparing spray tank mixtures with water of different sources and $\mathrm{pH}$. Some pesticides can degrade quickly in alkaline solutions (25); thus, additional studies are needed to evaluate $\mathrm{pH}$ of spray solutions and their effect on the activity of kasugamycin in managing fire blight. Additionally, these results indicate that the in vitro inhibitory concentration ranges for kasugamycin that we present in this study may not reflect the inhibitory activity of the compound in and on the host plant, where nutritional and other chemical conditions are complex. Thus, considering the high efficacy of the compound in our field studies, it is possible that the activity of kasugamycin may be enhanced in planta due to $\mathrm{pH}$ effects alone. The $\mathrm{pH}$ of pear flowers and leaves was measured and determined to be between 5 and 6 (J. E. Adaskaveg, unpublished). Still, the baseline concentration ranges that we established using defined laboratory conditions will be an important guideline in future monitoring programs aimed at preventing the establishment and spread of resistant populations of the pathogen.

Using a large collection of strains of E. amylovora with a wide range of sensitivities against streptomycin or oxytetracycline $(1,3)$, the regression analyses resulted in highly significant models. Low correlation coefficients, however, were found between sensitivity to kasugamycin and that to either of the other two antibiotics. Thus, cross resistance was not observed within the sample population although two of the antibiotics (i.e., kasugamycin and streptomycin) are aminoglycoside antibiotics $(27,31)$. This reflects the

Table 4. In vitro lowest inhibitory concentration (LIC) values (lowest concentration where a reduction of growth is observed) for kasugamycin, streptomycin, and oxytetracycline against Erwinia amylovora using selected agar media

\begin{tabular}{lccc}
\hline & \multicolumn{3}{c}{ LIC (mg/liter) } \\
\cline { 2 - 4 } Agar medium $^{\mathbf{z}}$ & Kasugamycin $^{\mathbf{S}}$ & Streptomycin & Oxytetracycline \\
\hline NA & $6.93 \mathrm{e}$ & $0.30 \mathrm{~cd}$ & $0.11 \mathrm{e}$ \\
Czapek & $12.25 \mathrm{~d}$ & $0.23 \mathrm{~d}$ & $0.72 \mathrm{bc}$ \\
KMB & $20.63 \mathrm{c}$ & $0.29 \mathrm{~cd}$ & $0.67 \mathrm{c}$ \\
523 & $28.54 \mathrm{~b}$ & $0.36 \mathrm{c}$ & $0.82 \mathrm{~b}$ \\
LBA & $43.09 \mathrm{a}$ & $0.79 \mathrm{~b}$ & $0.36 \mathrm{~d}$ \\
YSA & $45.58 \mathrm{a}$ & $1.26 \mathrm{a}$ & $2.16 \mathrm{a}$ \\
\hline
\end{tabular}

${ }^{y}$ LICs were determined using the spiral gradient dilution method. Values are the average of eight isolates of E. amylovora from two repeated experiments. For each column, values followed by the same letter are not significantly different according to an analysis of variance and least significant mean separation procedures $(P<0.05)$.

${ }^{\mathrm{z}} \mathrm{NA}=$ nutrient agar, $\mathrm{KMB}=$ King's medium $\mathrm{B}, \mathrm{LBA}=$ Luria-Bertani agar, $523=$ Kado medium 523, and YSA = yeast-salts agar.

Table 5. In vitro inhibitory effect of kasugamycin on growth of Erwinia amylovora at two $\mathrm{pH}$ values

\begin{tabular}{lrr}
\hline & \multicolumn{2}{c}{ Growth $(\%)^{\mathbf{z}}$} \\
\cline { 2 - 3 } Kasugamycin (mg/liter) & pH 5.1 & pH 7.3 \\
\hline 0 & $100.0 \mathrm{Aa}$ & $100.0 \mathrm{Aa}$ \\
5 & $13.8 \mathrm{Bb}$ & $78.9 \mathrm{Ba}$ \\
10 & $3.9 \mathrm{Cb}$ & $64.9 \mathrm{Ca}$ \\
\hline
\end{tabular}

${ }^{\mathrm{z}}$ Growth in microtiter plates was measured as optical density. For each $\mathrm{pH}$ treatment, growth in the presence of kasugamycin was expressed as percent growth compared with the nonamended control. $\mathrm{pH}$ of nutrient broth was adjusted using a citrate-glycine-potassium phosphate buffer. Values are the average from three experiments, and values followed by the same letter (uppercase letters for each column and lowercase letters for each row) are not significantly different according to an analysis of variance and least significant mean separation procedures $(P<0.05)$. 
unique modes of action of each of the antibiotics. The sensitivity of strains to streptomycin appeared to be stepwise, with low and high levels of resistance measured within the sample populations. Streptomycin resistance levels ranged from 6 to $>50 \mathrm{mg} / \mathrm{liter}$. This possibly reflects the presence of different resistance genes and mechanisms, as has been described previously for E. amylovora $(13,18,23)$.

In 2005, the U.S. Environmental Protection Agency established import tolerances for kasugamycin on some agricultural crops. Subsequently, we requested a registration through Arysta LifeScience and the federal IR-4 Specialty Crop program for managing fire blight, walnut blight, and other bacterial diseases. The proposed registration that is expected for 2012 is based on a need for new compounds for managing bacterial plant diseases and represents the first antibiotic registered since the introduction of streptomycin in the 1950s and oxytetracycline in the 1970s. The results presented here will help in the design of integrated fire blight programs using a spectrum of different compounds with different modes of actions in rotations or mixtures to minimize selection processes that may result in resistant populations.

\section{Acknowledgments}

We thank R. Elkins and C. Ingels (University of California Cooperative Extension, Lake and Sacramento Counties, respectively) for their help in collecting diseased plant samples; A. Ha, N. Nguyen, K. Nguyen, and M. Vilchez for assistance in bacterial isolations and in laboratory sensitivity assays; and D. F. Thompson and J. K. Uyemoto for assistance in field studies.

\section{Literature Cited}

1. Adaskaveg, J. E., Driever, G. F., Förster, H., Gubler, W. D., Wade, L. M., and Holtz, B. 2008. Detection of Erwinia amylovora strains with reduced sensitivity to currently registered antibiotics and management of fire blight of pome fruits using kasugamycin in integrated strategies. Acta Hortic. 793:375-382

2. Adaskaveg, J. E., and Gubler, W. D. 2008. Evaluation of new bactericides for control of fire blight of pears caused by Erwinia amylovora. Pages 7582 in: California Pear Research Report 2008. California Pear Advisory Board. Online publication. http://www.calpear.com/

3. Adaskaveg, J. E., Wade, L., and Förster, H. 2007. Streptomycin resistance in Erwinia amylovora in California and a new bactericide for management of fire blight of pears. (Abstr.) Phytopathology 97:S2 .

4. Aldwinckle, H. S., and Norelli, J. L. 1990. Evaluation of Kasumin for control of fire blight. Proc. 5th Int. Workshop on Fire Blight. Acta Hortic. 273:391.

5. Bereswill, S., Pahl, A., Bellemann, P., Zeller, W., and Geider, K. 1992. Sensitive and species-specific detection of Erwinia amylovora by polymerase chain reaction analysis. Appl. Environ. Microbiol. 58:3522-2536.

6. Bonn, W. G. 1984. Efficacy of bactericides for the control of fire blight of pear. Acta Hortic. 151:205-208.

7. Bonn W. G., and van der Zwet, T. 2000. Distribution and economic importance of fire blight. Pages 37-53 in: Fire Blight. The Disease and its Causative Agent, Erwinia amylovora. J. L. Vanneste, ed. CABI Publishing, New York.

8. Brooks, A. N. 1926. Studies of the epidemiology and control of fire blight of apple. Phytopathology 16:665-696.

9. Förster, H., Kanetis, L., and Adaskaveg, J. E. 2004. Spiral gradient dilution, a rapid method for determining growth responses and 50\% effective concentration values in fungus-fungicide interactions. Phytopathology 94:163170.

10. Hamada, M., Hashimoto, T., Takahashi, T., Yokoyama, S., Miyake, M., Takeuchi, T., Okami, Y., and Umezawa, H. 1965. Antimicrobial activity of kasugamycin. J. Antibiot. Ser. A 18:104-106.

11. Johnson, K. B., and Stockwell, V. O. 2000. Biological control of fire blight. Pages 319-337 in: Fire Blight. The Disease and its Causative Agent, Erwinia amylovora. J. L. Vanneste, ed. CABI Publishing, New York.

12. Johnson, K. B., Stockwell, V. O., and Temple, T. N. 2008. Evaluation of kasugamycin as a component of an integrated biological and chemical strat- egy for suppression of blossom blight. Acta Hortic. 793:439-444.

13. Jones, A. L., and Schnabel, E. L. 2000. The development of streptomycinresistant strains of Erwinia amylovora. Pages 235-251 in: Fire Blight. The Disease and its Causative Agent, Erwinia amylovora. J. L. Vanneste, ed. CABI Publishing, New York.

14. Kado, C. I., and Heskett, M. G. 1970. Selective media for isolation of Agrobacterium, Corynebacterium, Erwinia, Pseudomonas, and Xanthomonas. Phytopathology 60:969-976.

15. King, E. O., Ward, M. K., and Raney, D. E. 1954. Two simple media for the demonstration of pyocyanin and fluorescein. J. Lab. Clin. Med. 44:301-307.

16. Koistra, T. S. J., and Langeslag, J. J. J. 1981. Experience with chemicals against E. amylovora. Acta Hortic. 117:97-106.

17. Lucas, G. B. 1955. The cardinal temperatures and $\mathrm{pH}$ response of Thielaviopsis basicola. Mycologia 47:793-798.

18. McManus, P. S., and Jones, A. L. 1994. Epidemiology and genetic analysis of streptomycin-resistant Erwinia amylovora from Michigan and evaluation of oxytetracycline for control. Phytopathology 84:627-633.

19. Misato, T., Ko, K., and Yamaguchi, I. 1977. Use of antibiotics in agriculture. Adv. Appl. Microbiol. 21:53-88.

20. Paton, J. H., Holt, H. A., and Bywater, M. J. 1990. Measurement of MICs of antibacterial agents by spiral gradient endpoint compared with conventional dilution method. Int. J. Exp. Clin. Chemother. 3:31-38.

21. Psallidas, P. G, and Tsiantos, J. 2000. Chemical control of fire blight. Pages 199-234 in: Fire Blight. The Disease and its Causative Agent, Erwinia amylovora. J. L. Vanneste, ed. CABI Publishing, New York.

22. Schroth, M. N., Moller, W. J., Thomson, S. V., and Hildebrand, D. C. 1974. Epidemiology and control of fire blight. Annu. Rev. Phytopathol. 12:389412.

23. Schroth, M. N., Thomson, S. V., and Moller, W. J. 1979. Streptomycin resistance in Erwinia amylovora. Phytopathology 69:565-568.

24. Scott, D. W. 1979. On optimal and data-based histograms. Biometrika 66:605-610.

25. Seaman, A. J., and Riedel, H. 1986. Preventing decomposition of agricultural chemicals by alkaline hydrolysis in the spray tank. N. Y. Food Life Sci. Bull. 118:1-7.

26. Sundin, G. W., Ehret, G. R., and McGhee, G. C. 2008. Fire blight control on Jonathan apple with antibiotics in 2008. Plant Dis. Manage. Rep. 3:PF027.

27. Tanaka, N., Yamaguchi, H., and Umezawa, H. 1966. Mechanism of kasugamycin action on polypeptide synthesis. J. Biochem. 60:429-434.

28. Thomson, S. V. 2000. Epidemiology of fire blight. Pages 9-36 in: Fire Blight. The Disease and its Causative Agent, Erwinia amylovora. J. L. Vanneste, ed. CABI Publishing, New York.

29. Tomlin, C. D. S. 2003. The Pesticide Manual. Thirteenth edition. British Crop Protection Council, Alton, UK.

30. Uesugi, Y. 1998. Fungicide classes: chemistry, uses and mode of action Pages 23-56 in: Fungicidal Activity. Chemical and Biological Approaches to Plant Protection. D. Hutson and J. Miyamoto, eds. John Wiley \& Sons, Chichester, UK.

31. Umezawa, H., Okami, Y., Hashimoto, T., Suhara, Y., Hamada, M., and Takeuchi, T. 1965. A new antibiotic, kasugamycin. J. Antibiot. Ser. A 18:101-103.

32. Van der Zwet, T., and Keil, H. L. 1979. Fire Blight. A Bacterial Disease of Rosaceous Plants. Unites States Department of Agriculture Handbook 510. Washington, DC

33. Ware, G. W. 1983. Pesticides, Theory and Application. W. H. Freeman and Co., San Francisco.

34. Wilson, E. E., Zeitoun, F. M., and Frederickson, D. L. 1967. Bacterial phloem canker, a new disease of Persian walnut trees. Phytopathology 57:618-621.

35. Yamaguchi, I. 1998. Natural product-derived fungicides as exemplified by the antibiotics. Pages 57-85 in: Fungicidal Activity. Chemical and Biological Approaches to Plant Protection. D. Hutson and J. Miyamoto, eds. John Wiley \& Sons, Chichester, UK.

36. Yoder, K. S., Cochran, A.E., II, Royston, W. S., Jr., and Kilmer, S. W. 2008 Test of antibiotics and SAR candidates for blossom blight control on Golden Delicious and Rome Beauty Apples, 2008. Plant Dis. Manage. Rep 3:PF003.

37. Zehr, E. I. 1968. Selected organic fungicides and dimethyl sulfoxide as supplements to streptomycin for fire blight control on Bartlett pear. Phytopathology 58:1624-1629.

38. Zehr, E. I., and Parker K. G. 1965. Control of fire blight in pear. Fungic. Nematicide Tests 21:43 